\title{
Circadian Rhythms in Exudative Age-Related Macular Degeneration: The Key Role of the Canonical WNT/ $\beta$-Catenin Pathway
}

\author{
Alexandre Vallée ${ }^{1, *(\mathbb{C})}$, Yves Lecarpentier ${ }^{2}$, Rodolphe Vallée ${ }^{3}$, Rémy Guillevin ${ }^{1}$ and \\ Jean-Noël Vallée ${ }^{4,5}$ \\ 1 DACTIM-MIS, Laboratory of Mathematics and Applications (LMA), UMR CNRS 7348, University of Poitiers, \\ CHU de Poitiers, 86021 Poitiers, France; remy.guillevin@chu-poitiers.fr \\ 2 Centre de Recherche Clinique, Grand Hôpital de l'Est Francilien (GHEF), 77100 Meaux, France; \\ yves.c.lecarpentier@gmail.com \\ 3 University Hospital Group of Paris-Seine-Saint-Denis, APHP, University of Paris-13 Sorbonne Paris-Cité, \\ 93000 Paris, France; rod.vallee@gmail.com \\ 4 CHU Amiens Picardie, University of Picardie Jules Verne (UPJV), 80000 Amiens, France; valleejn@gmail.com \\ 5 Laboratory of Mathematics and Applications (LMA), UMR CNRS 7348, University of Poitiers, \\ 86021 Poitiers, France \\ * Correspondence: alexandre.g.vallee@gmail.com; Tel.: +33629303240
}

Received: 10 December 2019; Accepted: 27 January 2020; Published: 27 January 2020

\begin{abstract}
Age-related macular degeneration (AMD) is considered as the main worldwide cause of blindness in elderly adults. Exudative AMD type represents 10 to $15 \%$ of macular degeneration cases, but is the main cause of vision loss and blindness. Circadian rhythm changes are associated with aging and could further accelerate it. However, the link between circadian rhythms and exudative AMD is not fully understood. Some evidence suggests that dysregulation of circadian functions could be manifestations of diseases or could be risk factors for the development of disease in elderly adults. Biological rhythms are complex systems interacting with the environment and control several physiological pathways. Recent findings have shown that the dysregulation of circadian rhythms is correlated with exudative AMD. One of the main pathways involved in exudative AMD is the canonical WNT/ $\beta$-catenin pathway. Circadian clocks have a main role in some tissues by driving the circadian expression of genes involved in physiological and metabolic functions. In exudative $\mathrm{AMD}$, the increase of the canonical WNT/ $\beta$-catenin pathway is enhanced by the dysregulation of circadian rhythms. Exudative AMD progression is associated with major metabolic reprogramming, initiated by aberrant WNT/ $\beta$-catenin pathway, of aerobic glycolysis. This review focuses on the interest of circadian rhythm dysregulation in exudative AMD through the aberrant upregulation of the canonical WNT/ $\beta$-catenin pathway.
\end{abstract}

Keywords: exudative AMD; circadian rhythms; WNT/ $\beta$-catenin pathway; aerobic glycolysis; Warburg effect

\section{Introduction}

Age-related macular degeneration (AMD) is considered as the main worldwide cause of blindness in elderly adults [1]. AMD progression is initially characterized by the primary influence of debris accumulation in the early step, whereas the late step presents an accumulation of retinal epithelial dysfunctions. AMD is divided into two types: "non-exudative" and "exudative" AMD. Non-exudative AMD is marked by a progressive loss of the retinal pigment epithelium (RPE) cell layer and thinning of the retina, while exudative AMD is characterized by choroidal neovascularization (CNV) and sub-retinal 
neovascular fibrous tissue [2], leading to central vision deterioration [3]. CNV is defined by abnormal blood vessels from the choroid underneath the macula [4]. The exudative AMD type represents 10 to $15 \%$ of macular degeneration cases, but this is the main cause of vision loss and blindness $[5,6]$ because CNV participates in $80 \%$ of this vision loss due to AMD [7]. CNV initiation is correlated with the enhancement of the proangiogenic factor vascular endothelial growth factor (VEGF) [8]. Currently, the molecular pathways involved in AMD still remain to be clarified. Nevertheless, the aging process is a main risk factor for neurodegeneration and then for exudative AMD. This process can disturb molecular pathways involving homeostatic mechanisms [9]. Exudative AMD undergoes metabolic reprogramming, closely associated with aging, called aerobic glycolysis, or the Warburg effect [10].

Circadian rhythm (CR) changes are associated with aging and could further accelerate it [11]. However, the link between CRs and exudative AMD is not fully understood. The dysregulation of circadian functions could be manifestations or risk factors for the development of diseases in elderly adults [12-15]. Indeed, circadian clocks have a main role in physiological and metabolic functions [16], and one of the key integrators of these metabolic mechanisms is the canonical $\mathrm{WNT} / \beta$-catenin pathway $[17,18]$. Exudative AMD is associated with the upregulation of this $W N T / \beta$-catenin pathway [19], leading to the activation of aerobic glycolysis [20]. In parallel, the dysregulation of CRs upregulates the WNT/ $\beta$-catenin pathway [21], which in turn participates in AMD. This review focuses on the interest of $C R$ dysregulation in exudative AMD through the aberrant upregulation of the canonical WNT/ $\beta$-catenin pathway.

\section{Circadian rhythms (CRs)}

The endogenous characteristic of CRs is an innate oscillation associated with a period of over one day. All of the studied organisms show this oscillatory process. Numerous cell functions present temporal variations driven by these oscillatory and circadian ways including gene expression, metabolic reprogramming, and molecular and cellular pathways. Different integration levels allow for the study of CRs as endocrinal, physiological, and neuronal cell behaviors. Although the coordination and the modulation of CRs are organized by specific pacemaker structures, the primary circadian oscillations are controlled at the cell level. These oscillations are determined by numerous clock genes [22]. The control of the circadian clock is based on an intracellular temporal tracking system that allows anterior organisms to change direction and thus adapt their behavior and the physiology of their life span [23]. It is well known that in many animal species, the circadian clock is formed by a specific set of transcription factors that constitutes its molecular architecture. These factors are used in a double feedback modulated by a cell-autonomous manner [24].

Endogenous oscillations generate a freewheeling period, which is close to $24 \mathrm{~h}$, at constant ambient conditions to maintain the organism. These oscillators, at the molecular level, are based on the products of clock regulator genes organized in a transcriptional feedback loop. Circadian oscillations are the product of post-transcriptional modifications of proteins [25]. A complex loop operates with clock gene transcriptional activators and in turn, the clock genes act with a negative feedback role to inhibit their own expression by disrupting the activity of their activators [26]. Several input pathways involve environmental information, which interact with the different compounds of the oscillators. The oscillators are synchronized with the $24 \mathrm{~h}$ solar day. The input pathways generate a day-time to transpose it by the oscillators to the output pathways. These output pathways control and regulate the expression of circadian clock genes to generate the rhythmicity.

Moreover, the output pathways are predicted to be rhythmic and then controlled by the clock gene transcription factors. These compounds, in turn, regulate downstream the circadian clock genes in a time-of-day-specific manner [27]. This system can synchronize with its environmental time through its internal clock. To respect the environment, the input pathways are vital to maintain this timing for oscillators. The process, named entrainment, acts on the input pathways to reset the activity of the oscillators and stay in a conformed $24 \mathrm{~h}$ period of the environment [27]. Environmental cues can be detected by input pathways, which in turn can modulate several mechanisms to control the activity 
or level of compounds of oscillators to keep a correct time of day expression. This phenomenon is observed in several environmental cues including nutrition, social interactions, and temperature $[28,29]$. Furthermore, the clock allows a strategy, named gating, to restrict responses to environmental cues at specific day times. Diurnal mammals are insensitive to a light pulse during the day. Nevertheless, during the night, a light pulse can advance or delay the clock to synchronize diurnal mammals with the environment [24]. Environmental signals can interact with molecular oscillators in some cells in complex multicellular organisms. In unicellular organisms, each cell is modulated by oscillators in response to light [30]. However, in multicellular organisms, only a part of the cells has sensory capabilities leading to clock oscillators. The oscillators, and thus, the overall rhythmicity of organisms, are concentrated into compounds including a master pacemaker and peripheral oscillators [31]. Faced with these sensory inputs, the organism presents some nervous systems that possess environmental cue abilities as central oscillators or pacemakers, rather than individual cells. In humans, sensory clock inputs are localized in the brain, where signals from the master pacemaker lead to oscillators in some tissues of the organism.

Photo-entrainment of the suprachiasmatic nucleus processes through pathways from a subpopulation of retinal ganglion cells (RGCs), which are melanospin-expressing and intrinsically photosensitive (ipRGCs) [32]. These retinal ganglion cells receive and perceive the light, and transmit this information to the master pacemaker (localized in the hypothalamus) by neural connections [33]. The central pacemaker synchronizes the oscillators to other tissues using circadian input pathways from the nervous system to peripheral cell systems. The central system allows cellular oscillations within tissues in an adequate phase to maintain the resonance between the different cellular rhythms involved by the environment [34]. Melatonin operates as a major synchronizer in humans and provides temporal feedback to the oscillators within the nervous system for controlling the circadian phase and the rhythm stability [35]. In humans, as in other mammals, melatonin is considered as an important influencer of CRs through its action on receptors in the nervous system [36].

\section{Circadian Clock}

In humans, many biological mechanisms are modulated by the circadian "clock" (circadian locomotors output cycles kaput) (Figure 1). The circadian clock is localized in the hypothalamic suprachiasmatic nucleus (SCN). CRs are endogenous and entrainable free-running $24 \mathrm{~h}$ periods. Numerous transcription factors can act on CRs. These factors are called circadian locomotor output cycles kaput (Clock), brain and muscle aryl-hydrocarbon receptor nuclear translocator-like 1 (Bmal1), Period 1 (Per1), Period 2 (Per2), Period 3 (Per3), and Cryptochrome (Cry 1 and Cry 2) [37,38]. These factors are controlled by positive and negative self-loop-regulation modulated by CRs [24,39]. Clock and Bmal1 heterodimerize, leading to the transcription of Per1, Per2, Cry1, and Cry2 [40]. The $\mathrm{Per} / \mathrm{Cry}$ heterodimer downregulates its stimulation through a negative feedback. This heterodimer translocates back to the nucleus to directly inhibit the Clock/Bmal1 complex and then downregulate its transcription [40]. The Clock/Bmal1 complex stimulates the transcription of retinoic acid-related orphan nuclear receptors, Rev-Erbs, and retinoid-related orphan receptors (RORs). Through a positive feedback loop, RORs activate the transcription of Bmal1, whereas through a negative feedback loop, Rev-Erb downregulates their transcription [40]. 


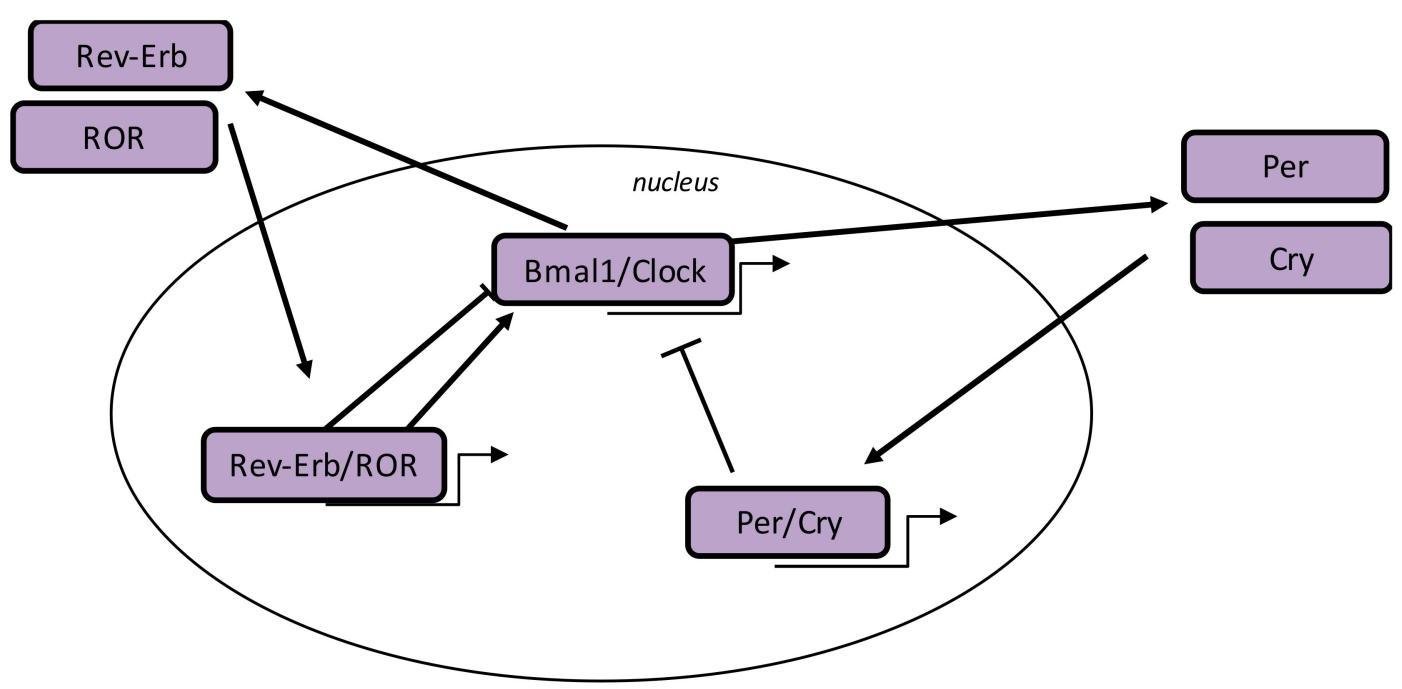

Figure 1. Circadian clock genes. The clock process is a stimulatory circle involving the Bmal1/Clock heterodimer that activates the transcription of Per and Cry genes, and the inhibitory feedback circle with the Per/Cry heterodimer that translocates to the nucleus and represses the transcription of the Clock and Bmal1 genes. An additional circle implicates the RORs and Rev-Erb factors with positive feedback by RORs and negative feedback by Rev-Erb. Abbreviations: circadian locomotor output cycles kaput (Clock), brain and muscle aryl-hydrocarbon receptor nuclear translocator-like 1 (Bmal1), period (Per), cryptochrome (Cry), and retinoid-related orphan receptors (RORs).

\section{Circadian Clocks in Exudative Age-Related Macular Degeneration}

A complex mechanism is involved in the retinal circadian system (Figure 2). This mechanism is composed of a complex circadian system associated with the generation of numerous CRs. Currently, the interaction between AMD and CRs has been poorly studied. However, some evidence has highlighted that physiological ocular mechanisms are controlled by CRs in humans. Photoreceptors renew their light-sensitive outer segments through disk shedding and the subsequent formation of new disks from the cilium of the inner segment. In vertebrates, CRs participate in the synchronization of outer segment renewal [41,42]. This phenomenon occurs once per day. Moreover, light onset is associated in synchronization with rod shedding in animals $[43,44]$. The outer segments should be shed, and the formation of new outer segments operates in coordination to maintain a constant length of photoreceptors. Some experimental studies in animal models have highlighted this association between CRs and AMD [45]. Dysregulation of the circadian clock by constant light exposure in zebrafish enhances the process of angiogenesis [45]. Activation of Bmal1 and Per2 leads to vascular initiation. Bmal1 targets VEGF in its promoter region to enhance its activity. In parallel, the deletion of the promoter region of the VEGF gene is associated with the inhibition of this promoter. Thus, these results could extend the development of angiogenesis in humans as the same process is observed in animals [46]. Dysfunction of the circadian clock system does not interact only with one physiological phenomenon, but participates in the progression of some diseases [47]. Melatonin is daily rhythmically produced by photoreceptors in the retina with an acrophase at night [48]. Numerous studies have shown that melatonin is involved in AMD progression [49,50]. Even if few studies have focused on the link between CRs, melatonin production, and AMD, some studies suggest that the melatonin rhythm is reversed in AMD [51]. 


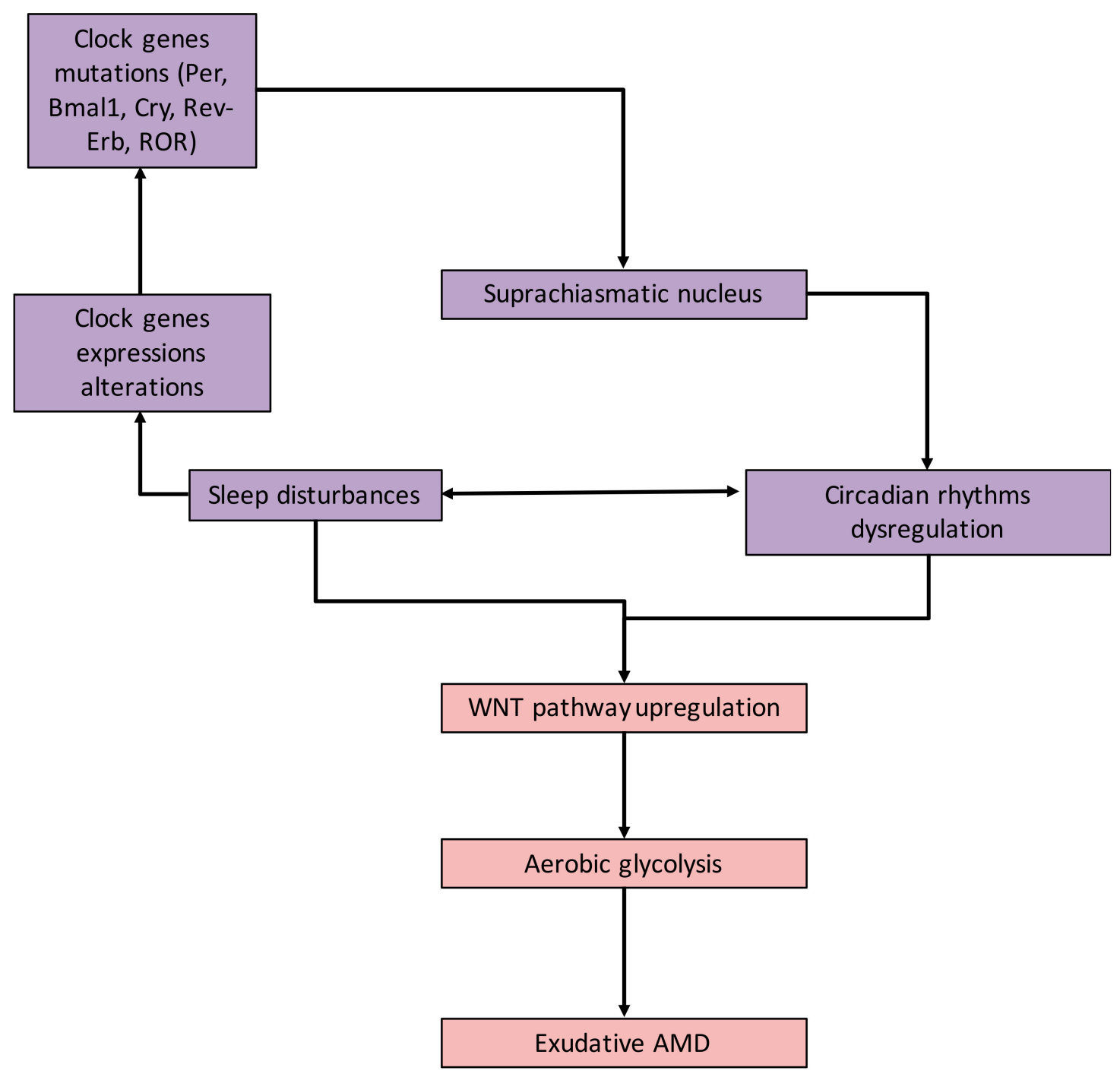

Figure 2. Circadian rhythms (CRs) and exudative Age-related macular degeneration (AMD). Relationship between exudative AMD, CRs, and sleep disturbance. Alterations in clock genes contribute to the dysregulation of circadian sleep rhythmicity. CR deregulation leads to brain metabolism alterations (i.e., aerobic glycolysis), contributing to exudative AMD. Abbreviations: age-related macular degeneration $(A M D)$, circadian locomotor output cycles kaput (Clock), brain and muscle aryl-hydrocarbon receptor nuclear translocator-like 1 (Bmal1), period (Per), cryptochrome (Cry) and retinoid-related orphan receptors (RORs).

\section{Aerobic Glycolysis and AMD}

In mammalian cells, glucose is the main source of energy. All tissues require ATP to operate in physiological conditions. Cells produce ATP through the drop-in oxidation state from glucose (energy-rich molecule) by cell respiration, down to producing $\mathrm{CO}_{2}$ at the end. This mechanism operates in an aerobic or anaerobic manner, which depends on the available $\mathrm{O}_{2}$. Glycolysis, which occurs in the cytoplasm of cells, is the first stage in the glucose metabolism pathway. The presence of $\mathrm{O}_{2}$ is major because glucose oxidation under aerobic conditions leads to 32 molecules of ATP per mol of glucose. Under anaerobic conditions, only two molecules of ATP can be produced. Aerobic glycolysis operates in two steps. The first step occurs in the cytosol and involves the conversion of one glucose into two molecules of pyruvate, resulting in NADH production and generating two molecules of ATP. In normal conditions, when oxygen is available, the energy contained in NADH is further released via re-oxidization of the mitochondrial chain and leads to the release of 38 molecules of ATP per 
molecule of glucose. Under aerobic glycolysis, this NADH, instead of re-oxidization, converts pyruvate to lactate [52]. Thus, glucose is metabolized in order to produce ATP through cytosolic glycolysis. Glucose entry into the tricarboxylic acid (TCA) cycle is modulated by pyruvate dehydrogenase complex $(P D H)$ [53]. In normal conditions, pyruvate is oxidized to acetyl-coA in mitochondria by the $P D H$. Acetyl-coA then translocates to the TCA cycle for oxidation. Under aerobic glycolysis, pyruvate is converted into lactate in the cytosol. This phenomenon is called aerobic glycolysis or the Warburg effect.

Several and multifactorial conditions could be associated with the pathogenesis of exudative AMD, including UV light exposure [54] and aging [55]. Nevertheless, few studies have highlighted that aerobic glycolysis can participate in the promotion of exudative AMD [56]. Photoreceptors from retinal glial cells produce lactate by glycolysis in the normal retina (Müller cells). Glucose, and then lactate, is consumed for oxidative metabolism in the photoreceptors [57]. Müller cells mainly produce ATP through the aerobic glycolysis process and less through oxygen consumption [58]. The retina needs a continuous flow in oxygen and glucose to maintain its physiological functions. Some studies have shown that the retina can require aerobic glycolysis as well as cancer cells [59-63]. To initiate the vision process, the retina can also utilize oxidative phosphorylation and aerobic glycolysis [62]. Nevertheless, the majority of glucose consumed by isolated retina, more than $80 \%$, is produced by aerobic glycolysis [63]. The observed production of lactate in the retina is associated with a high level of $\mathrm{O}_{2}$ consumption $[5,6,64]$.

The activated molecular pathways involved in aerobic glycolysis $[20,65,66]$ have also been observed in exudative AMD. The PI3K/Akt pathway is over-activated in exudative AMD [67-69] and is associated with the stimulation of HIF-1 $\alpha$ and VEGF activities [69]. Activated HIF-1 $\alpha$ releases VEGF that affects the functions of choroid and retinal endothelial cells and initiates the angiogenesis process in exudative AMD [70-72]. Pyruvate kinase activity produced by photoreceptors is associated with the involvement of aerobic glycolysis [73]. PKM2 is over-stimulated in exudative AMD [74]. In AMD, activation of EGFR leads to the transactivation of $\beta$-catenin and the transcription of cyclin D1 by a PKM2 positive feedback $[74,75]$.

Recent findings have shown that lactate levels are increased and pyruvate levels are decreased in exudative AMD. This suggests that aerobic glycolysis is preferred over oxidative phosphorylation in exudative AMD molecular process [76]. These results have shown a possible stimulation of $L D H-A$ leading to a production of lactate and a decrease in the pyruvate level entering the TCA cycle [76]. Moreover, in retina cells, the photoreceptors can metabolize glucose through the process of aerobic glycolysis in order to protect them against oxidative damage [77].

\section{Neovascularization and Warburg Effect}

$\mathrm{CNV}$ initiation involves the stimulation of VEGF activated by the WNT/ $\beta$-catenin pathway $[78,79]$. The decrease of $D K K 1$, a WNT inhibitor, is associated with exudative AMD, and then with the severity of $\mathrm{CNV}$ [80]. In exudative AMD, VEGF expression is stimulated by the aberrant $\mathrm{WNT} / \beta$-catenin pathway $[78,81,82]$. The WNT/ $\beta$-catenin pathway can directly stimulate the expression of VEGF in exudative AMD $[83,84]$ and is an upstream stimulator of the PI3K/Akt pathway [85] through the inhibition of GSK-3 $\beta$ [86]. Moreover, $\beta$-catenin signaling inhibition is associated with the decrease of the PI3K/Akt pathway $[87,88]$. Numerous studies have shown that the PI3K/Akt pathway is activated in exudative AMD [67-69] and can stimulate both HIF-1 $\alpha$ and VEGF [69]. VEGF production is stimulated by HIF- $1 \alpha$ to deteriorate the functions of choroid and retinal endothelial cells and to stimulate angiogenesis in exudative AMD [70-72]. The activation of $L D H-A$ is associated with VEGF stimulation [89-92]. Thus, the accumulation of lactate in the cytosol stimulates VEGF activity [93-95]. CNV formation is directly stimulated by overexpressing VEGF [96-99].

\section{CRs and Aerobic Glycolysis}

Few studies have focused on the relationship between CRs and aerobic glycolysis (Figure 3). Nevertheless, this relation could be mainly interesting in the development of tumors [100]. In 
the same way, melatonin modulation by CRs in cancers is associated with the disruption of aerobic glycolysis [101-103]. Thermodynamic and energy reprogramming highlight this relation in fibrosis [104], in neurodegenerative diseases [105,106], and in cancers [107]. The importance of 24-h fluctuations in aerobic glycolysis and the availability of NADPH in cancer have been shown through the consideration of the redox influence of NADPH [108].

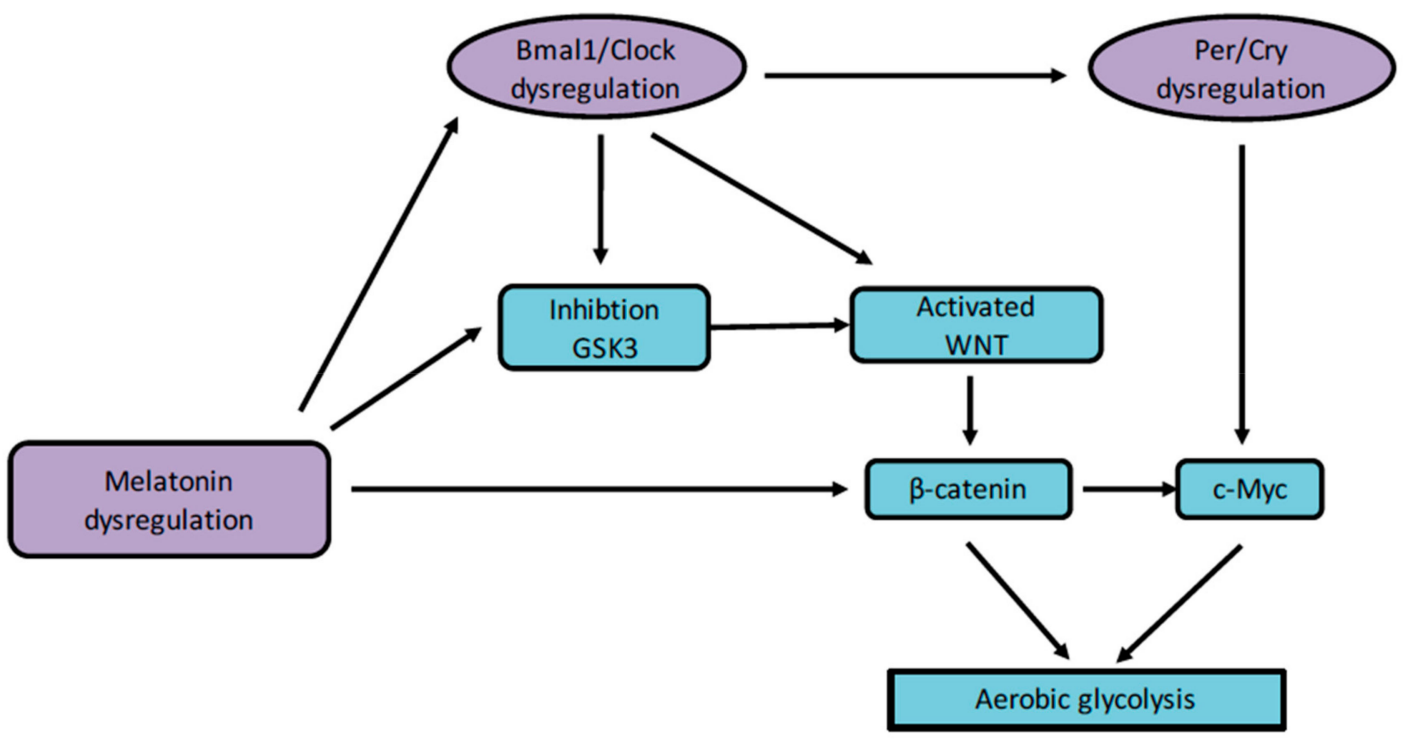

Figure 3. CRs and aerobic glycolysis. The dysregulation of melatonin and circadian clock genes leads to the activation of WNT and inactivation of GSK3. The WNT pathway enhances $\beta$-catenin accumulation and then, its nuclear translocation. Activation of the $\beta$-catenin pathway leads to aerobic glycolysis. Abbreviations: circadian locomotor output cycles kaput (Clock), brain and muscle aryl-hydrocarbon receptor nuclear translocator-like 1 (Bmal1), period (Per), cryptochrome (Cry), glycogen synthase kinase-3 $\beta(G S K-3 \beta)$.

\section{The Canonical WNT/ $\beta$-Catenin Pathway}

The Wingless/Int (WNT) pathway is a family of secreted lipid-modified glycoproteins [109]. Several pathophysiological processes are mediated by this pathway including fibrosis and angiogenesis $[17,110,111]$.

During eye development, WNT/ $\beta$-catenin pathway activity is highly mediated. Then, a dysfunction of the $\mathrm{WNT} / \beta$-catenin pathway leads to several ocular malformations due to defects in cell fate differentiation [112]. During the development of lens, the WNT/ $\beta$-catenin pathway is stimulated in the periocular surface ectoderm and lens epithelium $[113,114]$. For retinal development, the $\mathrm{WNT} / \beta$-catenin pathway is stimulated in the dorsal optic vesicle and then participates in the activation of retinal pigment epithelium (RPE) at the optic vesicle step. At this level, the WNT/ $\beta$-catenin pathway is contained inside the peripheral RPE [115]. The retinal vascular initiation is mainly modulated by the expression of the $\mathrm{WNT} / \beta$-catenin pathway [112]. In the retinal vascular system, the $\mathrm{WNT} / \beta$-catenin pathway is controlled by the erythroblast transformation-specific (ETS) transcription factor Erg. Erg has a main role in angiogenesis [116]. Erg modulates the WNT/ $\beta$-catenin pathway by promoting $\beta$-catenin stability and by regulating the transcription of Frizzled 4 (FZD4) (Figure 4) [116]. 


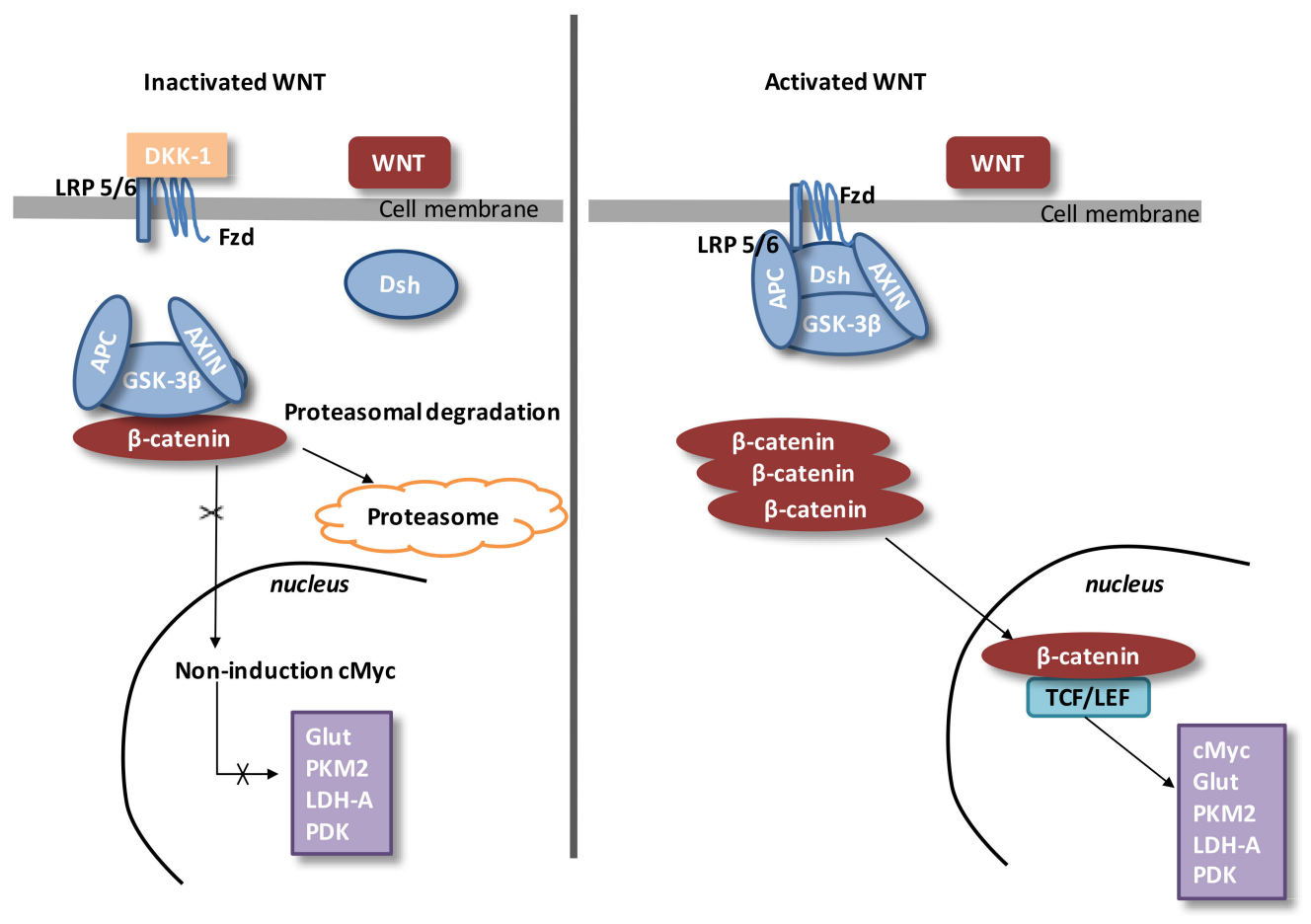

Figure 4. The canonical WNT/ $\beta$-catenin pathway. Downregulated WNT. Under physiological conditions, the cytosolic $\beta$-catenin is bound to its complex destruction, which consists of APC, AXIN, and GSK-3 $\beta$. GSK-3 $\beta$ phosphorylates $\beta$-catenin. Then, phosphorylated $\beta$-catenin is suppressed into the proteasome. The cytosolic $\beta$-catenin level is conserved low in the absence of WNT ligands. If $\beta$-catenin is not accumulated in the nucleus, the TCF/LEF complex does not activate its target genes. DKK1 downregulates the WNT/ $\beta$-catenin pathway through the link to WNT ligands or LRP5/6. Upregulated WNT. When WNT ligands stimulate FZD and LRP5/6, DSH is activated and phosphorylated by FZD. In turn, phosphorylated $D S H$ stimulates $A X I N$, which comes off the $\beta$-catenin destruction complex. $\beta$-catenin escapes from phosphorylation to accumulate in the cytosol. Cytosolic $\beta$-catenin goes into the nucleus, where it complexes with TCF/LEF and activates the transcription of target genes. Abbreviations: tumor suppressor adenomatous polyposis coli (APC), circadian locomotor output cycles kaput (Clock), brain and muscle aryl-hydrocarbon receptor nuclear translocator-like 1 (Bmal1), dickkopf-related protein $1(D K K-1)$, disheveled (DSH), period (Per), cryptochrome (Cry), glycogen synthase kinase-3 $\beta$ $(G S K-3 \beta)$, frizzled $(F Z D)$, lactate dehydrogenase A $(L D H-A)$, low-density lipoprotein receptor-related protein 5/6 (LRP 5/6), glucose transporter (Glut), pyruvate dehydrogenase kinase (PDK), and t-cell factor/lymphoid enhancer-binding factor (TCF/LEF).

Stimulation of FZD4/ $\beta$-catenin signaling needs the presence of the complex LRP5/LRP6 [117]. LRP5 has a main role while LRP6 has a minor role in retinal vascularization [118,119]. Disheveled (Dsh) forms a complex with $A X I N$, and this prevents the phosphorylation of $\beta$-catenin by glycogen synthase

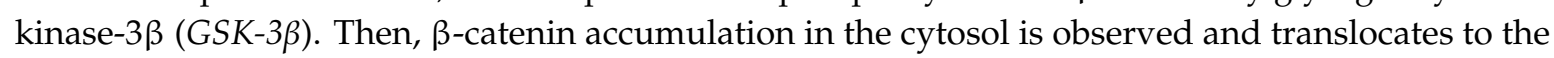
nucleus and binds the T-cell factor/lymphoid enhancer factor (TCF/LEF) co-transcription factors. This nuclear binding allows the transcription of WNT-responsive genes such as cyclin D1, c-Myc, PDK1, and MCT-1 [120,121].

In the absence of WNT ligands, cytosolic $\beta$-catenin is phosphorylated by GSK-3 $\beta$.

A destruction complex is composed of tumor suppressor adenomatous polyposis coli (APC), AXIN, GSK-3 $\beta$, and $\beta$-catenin. Then, phosphorylated $\beta$-catenin is destroyed into the proteasome. WNT inhibitors including DKKs and SFRPS control the WNT/ $\beta$-catenin pathway by preventing its ligand-receptor interactions [122].

GSK- $\beta$, an intracellular serin-threonin kinase, is a regulator of the WNT pathway [123]. GSK-3 $\beta$ regulates numerous pathophysiological pathways (cell membrane signaling, neuronal polarity, and 
inflammation) [124-126]. GSK-3 $\beta$ downregulates $\beta$-catenin cytosolic accumulation and then its nuclear translocation [124]. GSK-3 $\beta$ diminishes $\beta$-catenin, the mTOR pathway, HIF-1 $\alpha$, and VEGF expression [76].

\section{The Canonical WNT/ $\beta$-Catenin Pathway in Exudative AMD}

Aberrant activation of the $\mathrm{WNT} / \beta$-catenin pathway is associated with focal retinal degeneration and exudative AMD lesions [127]. Kallistatin, an endogenous antagonist of the WNT/ $\beta$-catenin pathway, is inhibited in AMD adults [127]. Kallistatin, a member of the serine proteinase inhibitor (SERPIN) family, can lead to anti-angiogenic and anti-inflammatory properties [78,128-132]. Kallistatin forms a complex with LRP6 to inhibit the WNT/ $\beta$-catenin pathway [131,132]. In murine models with focal retinal AMD-like lesions, administration of the anti-LRP6 antibody downregulates the $\mathrm{WNT} / \beta$-catenin pathway and stops the formation of retinal lesions [127].

Tissue factor (TF), a transmembrane cell-surface receptor for plasma coagulation factor VII, is considered as the major effector of the extrinsic coagulation pathway [133]. TF possesses proangiogenic roles in the stages of neovascularization formation [134-136]. Activation of TF is associated with exudative AMD retina [135] and its activation allows the initiation of exudative AMD through inflammatory processes $[135,137-139]$ and angiogenesis $[139,140]$. TF activates VEGF expression and participates in vascular formation by activating the WNT/ $\beta$-catenin pathway [141]. The WNT/ $\beta$-catenin pathway is downregulated in CNV models by the overexpression of Mab2F1 to reduce retinal vascular leakage [83,142]. Mab2F1 is a monoclonal antibody specific for $L R P 6$, and its use shows the main role played by the $W N T / \beta$-catenin pathway in exudative AMD.

A recent study has observed that the diminution of $D K K-1$ circulating levels was correlated with exudative AMD [80]. Decreased levels of $D K K-1$ are associated with exudative AMD severity and CNV initiation [80]. Causes of decreased DKK-1 levels are not well-known, but some studies have shown that circulating DKK-1 originates from the platelets [143].

The stimulation of the WNT/ $\beta$-catenin pathway leads to the over-expression of VEGF, TNF- $\alpha$, and ICAM-1 [78,81,82]. VEGF-activated by TNF- $\alpha$ has a key role in CNV [96-99]. TNF- $\alpha$ is overexpressed in exudative AMD [144,145], whereas ICAM-1 is still constitutively expressed in the RPE and plays a main role for leukocyte adherence $[146,147]$. Numerous studies have reported several relationships between the WNT/ $\beta$-catenin pathway and inflammation including TNF- $\alpha$ and $N F-\lambda B[17,148,149]$. Inflammation is a main factor in AMD through the stimulation of $V E G F$ activated by the $W N T / \beta$-catenin pathway $[78,79,150,151]$.

\section{CRs and WNT/ $\beta$-Catenin Pathway}

RORs are upstream effectors of the WNT/ $\beta$-catenin pathway [152]. Through this interaction, circadian genes can modulate the cell cycle progression [153]. A Bmal1 knockdown can downregulate the WNT/ $\beta$-catenin pathway [154]. In wild-type mice, the levels of WNT-related genes are higher than those observed in Bmal1 knockdown mice [155,156]. The proliferation of cells is controlled by Bmal1 through the activation of the WNT/ $\beta$-catenin pathway [157]. Bmal1 involves $\beta$-catenin transcription, diminishes $\beta$-catenin degradation, and inhibits GSK-3 $\beta$ activity [158]. In the intestinal mucosa of ApcMin/+ mice, the degradation of Per 2 leads to an increase in $\beta$-catenin through circadian disruption [159].

In normal conditions, the core circadian genes operate in accurate feedback loops and keep the molecular clockworks in the suprachiasmatic nucleus (SCN). They allow for the control of peripheral clocks [24,39]. Per1 and Per2 maintain cell CRs and modulate cell-related gene activity such as c-Myc, so as to sustain the physiological cell cycle $[160,161]$.

\section{Aerobic Glycolysis and the WNT/ $\beta$-Catenin Pathway}

Some reports have highlighted that the $\mathrm{WNT} / \beta$-catenin pathway is a main effector of aerobic glycolysis (Figure 5) $[10,15,20,66,104]$. The PI3K/Akt pathway stimulates glucose metabolism to enhance 
protein and lipid syntheses [162]. Moreover, the PI3K/Akt pathway increases glucose metabolism to protect cells against reactive oxygen species (ROS) stress induced by activated HIF-1 $\alpha$ [163]. HIF-1 $\alpha$ stimulates pyruvate dehydrogenase kinase $(P D K)$ to phosphorylate $P D H$ and inactivates it, leading to cytosolic pyruvate being shunted into lactate by $L D H-A$ [164]. HIF-1 $\alpha$ is transcriptionally activated by the PI3K/Akt/mTOR pathway through 4E-BP1 and STAT3 [165-170].

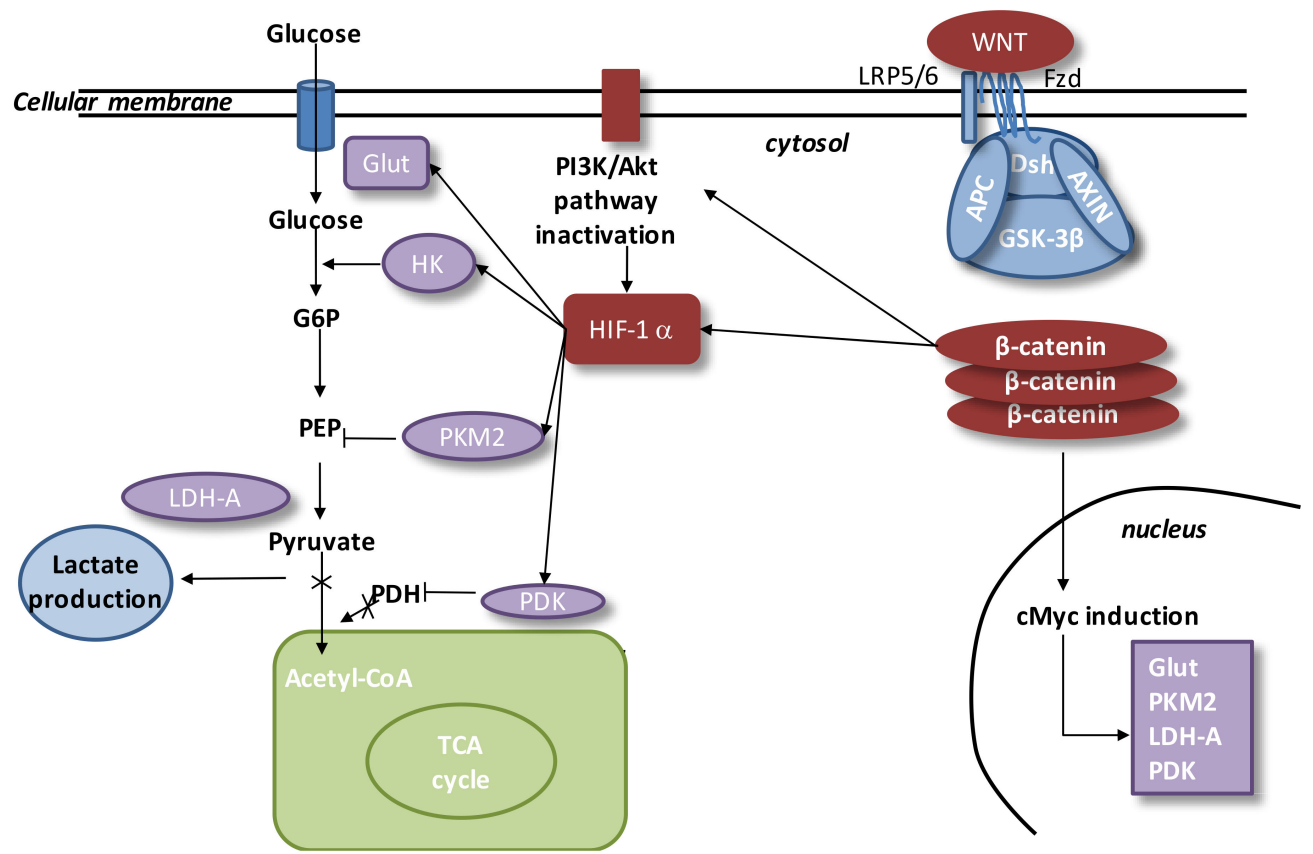

Figure 5. Interactions between the WNT pathway and aerobic glycolysis in exudative AMD. In exudative AMD, the WNT pathway is activated. In the presence of WNT ligands, cytosolic $\beta$-catenin

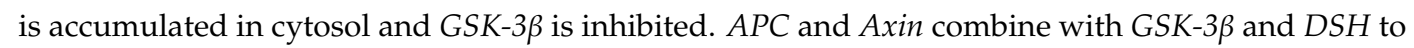
form a complex with LRP 5/6 and FZD. $\beta$-catenin translocates to the nucleus and binds to TCF/LEF co-transcription factor. WNT target genes such as $c M y c$ are activated. $\beta$-catenin accumulation increases the level of the PI3K/Akt pathway and results in activation of HIF-1 $\alpha$. Activated HIF-1 $\alpha$ stimulates Glut, HK, PKM2, LDH-A, and PDK1. Activation of HIF-1 $\alpha$ involves PKM2 translocation to the nucleus. PKM2 activates the PEP cascade and the formation of pyruvate. PKM2 binds to $\beta$-catenin and induces cMyc-mediated expression of glycolytic enzymes (Glut, $L D H-A, P D K 1)$. Activation of Glut and $H K$ involves glucose hyper-metabolism with an increase in glucose transport and phosphorylation rates. $P D K 1$ inhibits $P D H$ and downregulates the pyruvate entrance into mitochondria. Lactate production is activated by $L D H-A$. This is the aerobic glycolysis. Abbreviations: tumor suppressor adenomatous polyposis coli $(A P C)$, dickkopf-related protein $1(D K K-1)$, glucose 6 phosphate $(G 6 P)$, disheveled $(D S H)$, hexokinase $(H K)$, glycogen synthase kinase-3 $\beta(G S K-3 \beta)$, lactate dehydrogenase A $(L D H-A)$, glucose transporter $(G l u t)$, phosphoenolpyruvate $(P E P)$, pyruvate dehydrogenase kinase $(P D K)$, t-cell factor/lymphoid enhancer-binding factor (TCF/LEF), frizzled (FZD), low-density lipoprotein receptor-related protein 5/6 (LRP 5/6), and tricarboxylic acid cycle (TCA).

Numerous studies have observed that the WNT/ $\beta$-catenin pathway can downregulate pyruvate oxidation in the TCA cycle $[20,171]$. The WNT/ $\beta$-catenin pathway, by activating both the PI3K/Akt/mTOR pathway and HIF-1 $\alpha$, can lead to aerobic glycolysis [171,172]. The PI3K/Akt pathway controls $\beta$-catenin accumulation [173]. $c-M y c$ directly stimulates HIF-1 $\alpha$ [174], PDK, and lactate transporter (MCT-1) expression [171]. The stimulation of HIF-1 $\alpha$ leads to the overexpression of glucose transporters (Glut), hexokinase (HK), pyruvate kinase (PK), PDK1, and LDH-A [175-178]. 


\section{Conclusions}

Changes in energy metabolism are associated with metabolic and thermodynamic alterations and abnormal CRs in exudative AMD. In exudative AMD, the canonical WNT/ $\beta$-catenin pathway is increased. Energy behaviors of metabolic enzymes in exudative AMD are modified by this upregulation of the WNT/ $\beta$-catenin pathway, leading to the enhancement of aerobic glycolysis and thus the production of lactate. This explains the glucose hyper-metabolism observed in exudative AMD cells. The WNT pathway is driven by the CRs and operates under a circadian regime evolving to changes in energy metabolism. Regulation of the WNT/ $\beta$-catenin pathway is directly controlled by CRs and the impairment of these rhythms is involved in reprogramming energy metabolism, enabling exudative AMD.

Author Contributions: All authors listed have contributed to the work, and approved it for submitting to publication. All authors have read and agreed to the published version of the manuscript.

Conflicts of Interest: The authors declare that the research was conducted in the absence of any commercial or financial relationship that could be construed as a potential conflict of interest.

\section{Abbreviations}

$\begin{array}{ll}\text { AMD } & \text { Aged-macular degeneration } \\ \text { Bmal1 } & \text { Brain and muscle aryl-hydrocarbon receptor nuclear translocator-like 1 } \\ \text { Clock } & \text { Circadian locomotor output cycles kaput } \\ \text { CRs } & \text { Circadian rhythms } \\ \text { Per } & \text { Period } \\ \text { RORs } & \text { Retinoid-related orphan receptors; } \\ \text { NF- } \kappa \text { B } & \text { Nuclear factor } \kappa \text { B } \\ \text { TNF } & \text { Tumor necrosis factor }\end{array}$

\section{References}

1. Bird, A.C. Therapeutic targets in age-related macular disease. J. Clin. Invest. 2010, 120, 3033-3041. [CrossRef] [PubMed]

2. Ding, X.; Patel, M.; Chan, C.-C. Molecular pathology of age-related macular degeneration. Prog. Retin. Eye Res. 2009, 28, 1-18. [CrossRef] [PubMed]

3. Ferris, F.L.; Davis, M.D.; Clemons, T.E.; Lee, L.-Y.; Chew, E.Y.; Lindblad, A.S.; Milton, R.C.; Bressler, S.B.; Klein, R. Age-Related Eye Disease Study (AREDS) Research Group A simplified severity scale for age-related macular degeneration: AREDS Report No. 18. Arch. Ophthalmol. Chic. Ill 1960 2005, 123, 1570-1574.

4. Shao, J.; Choudhary, M.M.; Schachat, A.P. Neovascular Age-Related Macular Degeneration. Dev. Ophthalmol. 2016, 55, 125-136.

5. Coffe, V.; Carbajal, R.C.; Salceda, R. Glucose metabolism in rat retinal pigment epithelium. Neurochem. Res. 2006, 31, 103-108. [CrossRef]

6. Kaur, C.; Foulds, W.S.; Ling, E.-A. Hypoxia-ischemia and retinal ganglion cell damage. Clin. Ophthalmol. Auckl. NZ 2008, 2, 879-889. [CrossRef]

7. Ferris, F.L.; Fine, S.L.; Hyman, L. Age-related macular degeneration and blindness due to neovascular maculopathy. Arch. Ophthalmol. Chic. Ill 1960 1984, 102, 1640-1642. [CrossRef]

8. Barchitta, M.; Maugeri, A. Association between Vascular Endothelial Growth Factor Polymorphisms and Age-Related Macular Degeneration: An Updated Meta-Analysis. Dis. Markers 2016, 2016, 8486406. [CrossRef]

9. Yin, F.; Boveris, A.; Cadenas, E. Mitochondrial energy metabolism and redox signaling in brain aging and neurodegeneration. Antioxid. Redox Signal. 2014, 20, 353-371. [CrossRef]

10. Vallée, A.; Lecarpentier, Y.; Guillevin, R.; Vallée, J.-N. Aerobic Glycolysis Hypothesis Through WNT/Beta-Catenin Pathway in Exudative Age-Related Macular Degeneration. J. Mol. Neurosci. MN 2017, 62, 368-379. [CrossRef]

11. Leng, Y.; Musiek, E.S.; Hu, K.; Cappuccio, F.P.; Yaffe, K. Association between circadian rhythms and neurodegenerative diseases. Lancet Neurol. 2019, 18, 307-318. [CrossRef] 
12. Chellappa, S.L.; Vujovic, N.; Williams, J.S.; Scheer, F.A.J.L. Impact of Circadian Disruption on Cardiovascular Function and Disease. Trends Endocrinol. Metab. TEM 2019, 30, 767-779. [CrossRef] [PubMed]

13. Serin, Y.; Acar Tek, N. Effect of Circadian Rhythm on Metabolic Processes and the Regulation of Energy Balance. Ann. Nutr. Metab. 2019, 74, 322-330. [CrossRef] [PubMed]

14. Vallée, A.; Lecarpentier, Y.; Vallée, J.-N. Targeting the Canonical WNT/ $\beta$-Catenin Pathway in Cancer Treatment Using Non-Steroidal Anti-Inflammatory Drugs. Cells 2019, 8. [CrossRef] [PubMed]

15. Vallée, A.; Lecarpentier, Y.; Vallée, J.-N. Circadian Rhythms and Energy Metabolism Reprogramming in Parkinson's Disease. Curr. Issues Mol. Biol. 2019, 31, 21-44. [CrossRef] [PubMed]

16. Richards, J.; Gumz, M.L. Advances in understanding the peripheral circadian clocks. FASEB J. Off. Publ. Fed. Am. Soc. Exp. Biol. 2012, 26, 3602-3613. [CrossRef] [PubMed]

17. Logan, C.Y.; Nusse, R. The Wnt signaling pathway in development and disease. Annu. Rev. Cell Dev. Biol. 2004, 20, 781-810. [CrossRef]

18. Nusse, R.; Clevers, H. Wnt/ $\beta$-Catenin Signaling, Disease, and Emerging Therapeutic Modalities. Cell 2017, 169, 985-999. [CrossRef]

19. Vallée, A.; Lecarpentier, Y.; Guillevin, R.; Vallée, J.-N. PPAR $\gamma$ agonists: Potential treatments for exudative age-related macular degeneration. Life Sci. 2017, 188, 123-130. [CrossRef]

20. Thompson, C.B. Wnt meets Warburg: Another piece in the puzzle? EMBO J. 2014, 33, 1420-1422. [CrossRef]

21. Matsu-Ura, T.; Moore, S.R.; Hong, C.I. WNT Takes Two to Tango: Molecular Links between the Circadian Clock and the Cell Cycle in Adult Stem Cells. J. Biol. Rhythms 2018, 33, 5-14. [CrossRef] [PubMed]

22. Mackey, S.R.; Golden, S.S.; Ditty, J.L. The itty-bitty time machine genetics of the cyanobacterial circadian clock. Adv. Genet. 2011, 74, 13-53. [PubMed]

23. Dunlap, J.C. Molecular bases for circadian clocks. Cell 1999, 96, 271-290. [CrossRef]

24. Reppert, S.M.; Weaver, D.R. Coordination of circadian timing in mammals. Nature 2002, 418, 935-941. [CrossRef]

25. Hastings, M.H.; Maywood, E.S.; Brancaccio, M. The Mammalian Circadian Timing System and the Suprachiasmatic Nucleus as Its Pacemaker. Biology 2019, 8. [CrossRef]

26. Atger, F.; Mauvoisin, D.; Weger, B.; Gobet, C.; Gachon, F. Regulation of Mammalian Physiology by Interconnected Circadian and Feeding Rhythms. Front. Endocrinol. 2017, 8, 42. [CrossRef]

27. Johnson, C.H.; Elliott, J.A.; Foster, R. Entrainment of circadian programs. Chronobiol. Int. 2003, 20, 741-774. [CrossRef]

28. Carneiro, B.T.S.; Araujo, J.F. Food entrainment: major and recent findings. Front. Behav. Neurosci. 2012, 6, 83. [CrossRef]

29. Bloch, G.; Herzog, E.D.; Levine, J.D.; Schwartz, W.J. Socially synchronized circadian oscillators. Proc. Biol. Sci. 2013, 280, 20130035. [CrossRef]

30. Bell-Pedersen, D.; Cassone, V.M.; Earnest, D.J.; Golden, S.S.; Hardin, P.E.; Thomas, T.L.; Zoran, M.J. Circadian rhythms from multiple oscillators: Lessons from diverse organisms. Nat. Rev. Genet. 2005, 6, 544-556. [CrossRef]

31. Mohawk, J.A.; Green, C.B.; Takahashi, J.S. Central and peripheral circadian clocks in mammals. Annu. Rev. Neurosci. 2012, 35, 445-462. [CrossRef] [PubMed]

32. Kofuji, P.; Mure, L.S.; Massman, L.J.; Purrier, N.; Panda, S.; Engeland, W.C. Intrinsically Photosensitive Retinal Ganglion Cells (ipRGCs) Are Necessary for Light Entrainment of Peripheral Clocks. PLoS ONE 2016, 11, e0168651. [CrossRef] [PubMed]

33. Paul, K.N.; Saafir, T.B.; Tosini, G. The role of retinal photoreceptors in the regulation of circadian rhythms. Rev. Endocr. Metab. Disord. 2009, 10, 271-278. [CrossRef] [PubMed]

34. Dibner, C.; Schibler, U.; Albrecht, U. The mammalian circadian timing system: Organization and coordination of central and peripheral clocks. Annu. Rev. Physiol. 2010, 72, 517-549. [CrossRef]

35. Cassone, V.M. Effects of melatonin on vertebrate circadian systems. Trends Neurosci. 1990, 13, $457-464$. [CrossRef]

36. Weaver, D.R.; Stehle, J.H.; Stopa, E.G.; Reppert, S.M. Melatonin receptors in human hypothalamus and pituitary: Implications for circadian and reproductive responses to melatonin. J. Clin. Endocrinol. Metab. 1993, 76, 295-301. 
37. Hogenesch, J.B.; Gu, Y.Z.; Jain, S.; Bradfield, C.A. The basic-helix-loop-helix-PAS orphan MOP3 forms transcriptionally active complexes with circadian and hypoxia factors. Proc. Natl. Acad. Sci. U. S. A. 1998, 95, 5474-5479. [CrossRef]

38. Gekakis, N.; Staknis, D.; Nguyen, H.B.; Davis, F.C.; Wilsbacher, L.D.; King, D.P.; Takahashi, J.S.; Weitz, C.J. Role of the CLOCK protein in the mammalian circadian mechanism. Science 1998, 280, 1564-1569. [CrossRef]

39. Schibler, U.; Sassone-Corsi, P. A web of circadian pacemakers. Cell 2002, 111, 919-922. [CrossRef]

40. Ko, C.H.; Takahashi, J.S. Molecular components of the mammalian circadian clock. Hum. Mol. Genet. 2006, 15 Spec No 2, R271-R277. [CrossRef]

41. Young, R.W.; Bok, D. Participation of the retinal pigment epithelium in the rod outer segment renewal process. J. Cell Biol. 1969, 42, 392-403. [CrossRef]

42. LaVail, M.M. Rod outer segment disk shedding in rat retina: relationship to cyclic lighting. Science 1976, 194, 1071-1074. [CrossRef] [PubMed]

43. Young, R.W. The renewal of photoreceptor cell outer segments. J. Cell Biol. 1967, 33, 61-72. [CrossRef] [PubMed]

44. Goldman, A.I.; Teirstein, P.S.; O'Brien, P.J. The role of ambient lighting in circadian disc shedding in the rod outer segment of the rat retina. Invest. Ophthalmol. Vis. Sci. 1980, 19, 1257-1267. [PubMed]

45. Jensen, L.D.; Cao, Z.; Nakamura, M.; Yang, Y.; Bräutigam, L.; Andersson, P.; Zhang, Y.; Wahlberg, E.; Länne, T.; Hosaka, K.; et al. Opposing effects of circadian clock genes bmal1 and period2 in regulation of VEGF-dependent angiogenesis in developing zebrafish. Cell Rep. 2012, 2, 231-241. [CrossRef]

46. Jensen, L.D.; Cao, Y. Clock controls angiogenesis. Cell Cycle Georget. Tex 2013, 12, 405-408. [CrossRef] [PubMed]

47. Sahar, S.; Sassone-Corsi, P. Circadian clock and breast cancer: A molecular link. Cell Cycle Georget. Tex 2007, 6, 1329-1331.

48. Tosini, G.; Menaker, M. Circadian rhythms in cultured mammalian retina. Science 1996, $272,419-421$. [CrossRef]

49. Yi, C.; Pan, X.; Yan, H.; Guo, M.; Pierpaoli, W. Effects of melatonin in age-related macular degeneration. Ann. N. Y. Acad. Sci. 2005, 1057, 384-392. [CrossRef]

50. Rosen, R.; Hu, D.-N.; Perez, V.; Tai, K.; Yu, G.-P.; Chen, M.; Tone, P.; McCormick, S.A.; Walsh, J. Urinary 6-sulfatoxymelatonin level in age-related macular degeneration patients. Mol. Vis. 2009, 15, 1673-1679.

51. Schmid-Kubista, K.E.; Glittenberg, C.G.; Cezanne, M.; Holzmann, K.; Neumaier-Ammerer, B.; Binder, S. Daytime levels of melatonin in patients with age-related macular degeneration. Acta Ophthalmol. (Copenh.) 2009, 87, 89-93. [CrossRef] [PubMed]

52. Warburg, O. On the origin of cancer cells. Science 1956, 123, 309-314. [CrossRef] [PubMed]

53. Bender, T.; Martinou, J.-C. The mitochondrial pyruvate carrier in health and disease: To carry or not to carry? Biochim. Biophys. Acta 2016, 1863, 2436-2442. [CrossRef] [PubMed]

54. Chalam, K.V.; Khetpal, V.; Rusovici, R.; Balaiya, S. A review: Role of ultraviolet radiation in age-related macular degeneration. Eye Contact Lens 2011, 37, 225-232. [CrossRef]

55. Chakravarthy, U.; Wong, T.Y.; Fletcher, A.; Piault, E.; Evans, C.; Zlateva, G.; Buggage, R.; Pleil, A.; Mitchell, P. Clinical risk factors for age-related macular degeneration: A systematic review and meta-analysis. BMC Ophthalmol. 2010, 10, 31. [CrossRef]

56. Chiu, C.-J.; Taylor, A. Dietary hyperglycemia, glycemic index and metabolic retinal diseases. Prog. Retin. Eye Res. 2011, 30, 18-53. [CrossRef]

57. Poitry-Yamate, C.L.; Poitry, S.; Tsacopoulos, M. Lactate released by Müller glial cells is metabolized by photoreceptors from mammalian retina. J. Neurosci. Off. J. Soc. Neurosci. 1995, 15, 5179-5191. [CrossRef]

58. Winkler, B.S.; Arnold, M.J.; Brassell, M.A.; Puro, D.G. Energy metabolism in human retinal Müller cells. Invest. Ophthalmol. Vis. Sci. 2000, 41, 3183-3190.

59. Cohen, L.H.; Noell, W.K. Glucose catabolism of rabbit retina before and after development of visual function. J. Neurochem. 1960, 5, 253-276. [CrossRef]

60. Krebs, H.A. The Pasteur effect and the relations between respiration and fermentation. Essays Biochem. 1972, $8,1-34$.

61. Winkler, B.S. Glycolytic and oxidative metabolism in relation to retinal function. J. Gen. Physiol. 1981, 77, 667-692. [CrossRef] [PubMed] 
62. Ames, A.; Li, Y.Y.; Heher, E.C.; Kimble, C.R. Energy metabolism of rabbit retina as related to function: High cost of Na+ transport. J. Neurosci. Off. J. Soc. Neurosci. 1992, 12, 840-853. [CrossRef]

63. Wang, L.; Kondo, M.; Bill, A. Glucose metabolism in cat outer retina. Effects of light and hyperoxia. Invest. Ophthalmol. Vis. Sci. 1997, 38, 48-55. [PubMed]

64. Miceli, M.V.; Newsome, D.A.; Schriver, G.W. Glucose uptake, hexose monophosphate shunt activity, and oxygen consumption in cultured human retinal pigment epithelial cells. Invest. Ophthalmol. Vis. Sci. 1990, 31, 277-283. [PubMed]

65. Chen, Z.; Liu, M.; Li, L.; Chen, L. Involvement of the Warburg effect in non-tumor diseases processes. J. Cell. Physiol. 2018, 233, 2839-2849. [CrossRef] [PubMed]

66. Vallée, A.; Vallée, J.-N. Warburg effect hypothesis in autism Spectrum disorders. Mol. Brain 2018, 11, 1. [CrossRef] [PubMed]

67. Minet, E.; Michel, G.; Mottet, D.; Raes, M.; Michiels, C. Transduction pathways involved in Hypoxia-Inducible Factor-1 phosphorylation and activation. Free Radic. Biol. Med. 2001, 31, 847-855. [CrossRef]

68. Semenza, G. Signal transduction to hypoxia-inducible factor 1. Biochem. Pharmacol. 2002, 64, 993-998. [CrossRef]

69. Jin, J.; Yuan, F.; Shen, M.; Feng, Y.; He, Q. Vascular endothelial growth factor regulates primate choroid-retinal endothelial cell proliferation and tube formation through PI3K/Akt and MEK/ERK dependent signaling. Mol. Cell. Biochem. 2013, 381, 267-272. [CrossRef]

70. Zhang, P.; Wang, Y.; Hui, Y.; Hu, D.; Wang, H.; Zhou, J.; Du, H. Inhibition of VEGF expression by targeting HIF-1 alpha with small interference RNA in human RPE cells. Ophthalmol. J. Int. Ophtalmol. Int. J. Ophthalmol. Z. Augenheilkd. 2007, 221,411-417.

71. Zhang, P.; Zhang, X.; Hao, X.; Wang, Y.; Hui, Y.; Wang, H.; Hu, D.; Zhou, J. Rac1 activates HIF-1 in retinal pigment epithelium cells under hypoxia. Graefes Arch. Clin. Exp. Ophthalmol. Albrecht Von Graefes Arch. Klin. Exp. Ophthalmol. 2009, 247, 633-639. [CrossRef] [PubMed]

72. Arjamaa, O.; Nikinmaa, M.; Salminen, A.; Kaarniranta, K. Regulatory role of HIF-1alpha in the pathogenesis of age-related macular degeneration (AMD). Ageing Res. Rev. 2009, 8, 349-358. [CrossRef]

73. Lindsay, K.J.; Du, J.; Sloat, S.R.; Contreras, L.; Linton, J.D.; Turner, S.J.; Sadilek, M.; Satrústegui, J.; Hurley, J.B. Pyruvate kinase and aspartate-glutamate carrier distributions reveal key metabolic links between neurons and glia in retina. Proc. Natl. Acad. Sci. U. S. A. 2014, 111, 15579-15584. [CrossRef] [PubMed]

74. Morohoshi, K.; Ohbayashi, M.; Patel, N.; Chong, V.; Bird, A.C.; Ono, S.J. Identification of anti-retinal antibodies in patients with age-related macular degeneration. Exp. Mol. Pathol. 2012, 93, 193-199. [CrossRef] [PubMed]

75. Yang, X.; Chen, H.; Zhu, M.; Zhu, R.; Qin, B.; Fang, H.; Dai, M.; Sang, A.; Liu, X. Up-Regulation of PKM2 Relates to Retinal Ganglion Cell Apoptosis After Light-Induced Retinal Damage in Adult Rats. Cell. Mol. Neurobiol. 2015, 35, 1175-1186. [CrossRef]

76. Yokosako, K.; Mimura, T.; Funatsu, H.; Noma, H.; Goto, M.; Kamei, Y.; Kondo, A.; Matsubara, M. Glycolysis in patients with age-related macular degeneration. Open Ophthalmol. J. 2014, 8, 39-47. [CrossRef]

77. Léveillard, T.; Sahel, J.-A. Metabolic and redox signaling in the retina. Cell. Mol. Life Sci. CMLS 2016. [CrossRef]

78. Zhou, T.; Hu, Y.; Chen, Y.; Zhou, K.K.; Zhang, B.; Gao, G.; Ma, J. The pathogenic role of the canonical Wnt pathway in age-related macular degeneration. Invest. Ophthalmol. Vis. Sci. 2010, 51, 4371-4379. [CrossRef]

79. Ambati, J. Age-related macular degeneration and the other double helix. The Cogan Lecture. Invest. Ophthalmol. Vis. Sci. 2011, 52, 2165-2169. [CrossRef]

80. Qiu, F.; Liu, Z.; Zhou, Y.; He, J.; Gong, S.; Bai, X.; Zeng, Y.; Liu, Z.; Ma, J.-X. Decreased Circulating Levels of Dickkopf-1 in Patients with Exudative Age-related Macular Degeneration. Sci. Rep. 2017, 7, 1263. [CrossRef]

81. Zhang, X.; Gaspard, J.P.; Chung, D.C. Regulation of vascular endothelial growth factor by the Wnt and K-ras pathways in colonic neoplasia. Cancer Res. 2001, 61, 6050-6054. [PubMed]

82. Easwaran, V.; Lee, S.H.; Inge, L.; Guo, L.; Goldbeck, C.; Garrett, E.; Wiesmann, M.; Garcia, P.D.; Fuller, J.H.; Chan, V.; et al. beta-Catenin regulates vascular endothelial growth factor expression in colon cancer. Cancer Res. 2003, 63, 3145-3153. [PubMed]

83. Hu, Y.; Chen, Y.; Lin, M.; Lee, K.; Mott, R.A.; Ma, J. Pathogenic role of the Wnt signaling pathway activation in laser-induced choroidal neovascularization. Invest. Ophthalmol. Vis. Sci. 2013, 54, 141-154. [CrossRef] [PubMed] 
84. Liu, X. Overstimulation can create health problems due to increases in PI3K/Akt/GSK3 insensitivity and GSK3 activity. SpringerPlus 2014, 3, 356. [CrossRef]

85. Chen, J.; Alberts, I.; Li, X. Dysregulation of the IGF-I/PI3K/AKT/mTOR signaling pathway in autism spectrum disorders. Int. J. Dev. Neurosci. Off. J. Int. Soc. Dev. Neurosci. 2014, 35, 35-41. [CrossRef]

86. Huang, J.; Nguyen-McCarty, M.; Hexner, E.O.; Danet-Desnoyers, G.; Klein, P.S. Maintenance of hematopoietic stem cells through regulation of Wnt and mTOR pathways. Nat. Med. 2012, 18, 1778-1785. [CrossRef]

87. Park, K.S.; Lee, R.D.; Kang, S.-K.; Han, S.Y.; Park, K.L.; Yang, K.H.; Song, Y.S.; Park, H.J.; Lee, Y.M.; Yun, Y.P.; et al. Neuronal differentiation of embryonic midbrain cells by upregulation of peroxisome proliferator-activated receptor-gamma via the JNK-dependent pathway. Exp. Cell Res. 2004, 297, 424-433. [CrossRef]

88. Yue, X.; Lan, F.; Yang, W.; Yang, Y.; Han, L.; Zhang, A.; Liu, J.; Zeng, H.; Jiang, T.; Pu, P.; et al. Interruption of $\beta$-catenin suppresses the EGFR pathway by blocking multiple oncogenic targets in human glioma cells. Brain Res. 2010, 1366, 27-37. [CrossRef]

89. Koukourakis, M.I.; Giatromanolaki, A.; Sivridis, E.; Bougioukas, G.; Didilis, V.; Gatter, K.C.; Harris, A.L. Tumour and Angiogenesis Research Group Lactate dehydrogenase-5 (LDH-5) overexpression in non-small-cell lung cancer tissues is linked to tumour hypoxia, angiogenic factor production and poor prognosis. Br. J. Cancer 2003, 89, 877-885. [CrossRef]

90. Koukourakis, M.I.; Giatromanolaki, A.; Sivridis, E.; Gatter, K.C.; Trarbach, T.; Folprecht, G.; Shi, M.M.; Lebwohl, D.; Jalava, T.; Laurent, D.; et al. Prognostic and predictive role of lactate dehydrogenase 5 expression in colorectal cancer patients treated with PTK787/ZK 222584 (vatalanib) antiangiogenic therapy. Clin. Cancer Res. Off. J. Am. Assoc. Cancer Res. 2011, 17, 4892-4900. [CrossRef]

91. Giatromanolaki, A.; Sivridis, E.; Gatter, K.C.; Turley, H.; Harris, A.L.; Koukourakis, M.I. Tumour and Angiogenesis Research Group Lactate dehydrogenase 5 (LDH-5) expression in endometrial cancer relates to the activated VEGF/VEGFR2(KDR) pathway and prognosis. Gynecol. Oncol. 2006, 103, 912-918. [CrossRef] [PubMed]

92. Kolev, Y.; Uetake, H.; Takagi, Y.; Sugihara, K. Lactate dehydrogenase-5 (LDH-5) expression in human gastric cancer: Association with hypoxia-inducible factor (HIF-1alpha) pathway, angiogenic factors production and poor prognosis. Ann. Surg. Oncol. 2008, 15, 2336-2344. [CrossRef] [PubMed]

93. Dhup, S.; Dadhich, R.K.; Porporato, P.E.; Sonveaux, P. Multiple biological activities of lactic acid in cancer: Influences on tumor growth, angiogenesis and metastasis. Curr. Pharm. Des. 2012, 18, 1319-1330. [CrossRef] [PubMed]

94. Polet, F.; Feron, O. Endothelial cell metabolism and tumour angiogenesis: Glucose and glutamine as essential fuels and lactate as the driving force. J. Intern. Med. 2013, 273, 156-165. [CrossRef]

95. San-Millán, I.; Brooks, G.A. Reexamining cancer metabolism: Lactate production for carcinogenesis could be the purpose and explanation of the Warburg Effect. Carcinogenesis 2016. [CrossRef]

96. Ip, M.S.; Scott, I.U.; Brown, G.C.; Brown, M.M.; Ho, A.C.; Huang, S.S.; Recchia, F.M. American Academy of Ophthalmology Anti-vascular endothelial growth factor pharmacotherapy for age-related macular degeneration: A report by the American Academy of Ophthalmology. Ophthalmology 2008, 115, 1837-1846. [CrossRef]

97. Wolf, S. Current status of anti-vascular endothelial growth factor therapy in Europe. Jpn. J. Ophthalmol. 2008, 52, 433-439. [CrossRef]

98. Menon, G.; Walters, G. New paradigms in the treatment of wet AMD: The impact of anti-VEGF therapy. Eye Lond. Engl. 2009, 23 Suppl 1, S1-S7. [CrossRef]

99. Grisanti, S.; Zhu, Q.; Tatar, O.; Lueke, J.; Lueke, M.; Tura, A.; Grisanti, S. Differential expression of vascular endothelial growth factor-a isoforms in neovascular age-related macular degeneration. Retina Phila. Pa 2015, 35, 764-772. [CrossRef]

100. Cao, Y.; Wang, R.-H. Associations among Metabolism, Circadian Rhythm and Age-Associated Diseases. Aging Dis. 2017, 8, 314-333. [CrossRef]

101. Blask, D.E.; Dauchy, R.T.; Dauchy, E.M.; Mao, L.; Hill, S.M.; Greene, M.W.; Belancio, V.P.; Sauer, L.A.; Davidson, L. Light exposure at night disrupts host/cancer circadian regulatory dynamics: Impact on the Warburg effect, lipid signaling and tumor growth prevention. PLoS ONE 2014, 9, e102776. [CrossRef] [PubMed] 
102. Dauchy, R.T.; Hoffman, A.E.; Wren-Dail, M.A.; Hanifin, J.P.; Warfield, B.; Brainard, G.C.; Xiang, S.; Yuan, L.; Hill, S.M.; Belancio, V.P.; et al. Daytime Blue Light Enhances the Nighttime Circadian Melatonin Inhibition of Human Prostate Cancer Growth. Comp. Med. 2015, 65, 473-485. [PubMed]

103. Mao, L.; Dauchy, R.T.; Blask, D.E.; Dauchy, E.M.; Slakey, L.M.; Brimer, S.; Yuan, L.; Xiang, S.; Hauch, A.; Smith, K.; et al. Melatonin suppression of aerobic glycolysis (Warburg effect), survival signalling and metastasis in human leiomyosarcoma. J. Pineal Res. 2016, 60, 167-177. [CrossRef] [PubMed]

104. Vallée, A.; Lecarpentier, Y.; Vallée, J.-N. Thermodynamic Aspects and Reprogramming Cellular Energy Metabolism during the Fibrosis Process. Int. J. Mol. Sci. 2017, 18. [CrossRef]

105. Vallée, A.; Lecarpentier, Y.; Guillevin, R.; Vallée, J.-N. Reprogramming energetic metabolism in Alzheimer's disease. Life Sci. 2018, 193, 141-152. [CrossRef]

106. Vallée, A.; Lecarpentier, Y.; Guillevin, R.; Vallée, J.-N. Thermodynamics in Neurodegenerative Diseases: Interplay Between Canonical WNT/Beta-Catenin Pathway-PPAR Gamma, Energy Metabolism and Circadian Rhythms. Neuromolecular Med. 2018, 20, 174-204. [CrossRef]

107. Vallée, A.; Lecarpentier, Y.; Guillevin, R.; Vallée, J.-N. Thermodynamics in Gliomas: Interactions between the Canonical WNT/Beta-Catenin Pathway and PPAR Gamma. Front. Physiol. 2017, 8, 352. [CrossRef]

108. Méndez, I.; Vázquez-Martínez, O.; Hernández-Muñoz, R.; Valente-Godínez, H.; Díaz-Muñoz, M. Redox regulation and pro-oxidant reactions in the physiology of circadian systems. Biochimie 2016, 124, 178-186. [CrossRef]

109. Al-Harthi, L. Wnt/ $\beta$-catenin and its Diverse Physiological Cell Signaling Pathways in Neurodegenerative and Neuropsychiatric Disorders. J. Neuroimmune Pharmacol. 2012, 7, 725-730. [CrossRef]

110. Klaus, A.; Birchmeier, W. Wnt signalling and its impact on development and cancer. Nat. Rev. Cancer 2008, 8, 387-398. [CrossRef]

111. Fuhrmann, S. Wnt signaling in eye organogenesis. Organogenesis 2008, 4, 60-67. [CrossRef] [PubMed]

112. Fujimura, N. WNT/ $\beta$-Catenin Signaling in Vertebrate Eye Development. Front. Cell Dev. Biol. 2016, 4, 138. [CrossRef] [PubMed]

113. Machon, O.; Kreslova, J.; Ruzickova, J.; Vacik, T.; Klimova, L.; Fujimura, N.; Lachova, J.; Kozmik, Z. Lens morphogenesis is dependent on Pax6-mediated inhibition of the canonical Wnt/beta-catenin signaling in the lens surface ectoderm. Genes. N. Y. N 2000 2010, 48, 86-95. [CrossRef] [PubMed]

114. Carpenter, A.C.; Smith, A.N.; Wagner, H.; Cohen-Tayar, Y.; Rao, S.; Wallace, V.; Ashery-Padan, R.; Lang, R.A. Wnt ligands from the embryonic surface ectoderm regulate "bimetallic strip" optic cup morphogenesis in mouse. Dev. Camb. Engl. 2015, 142, 972-982. [CrossRef]

115. Hägglund, A.-C.; Berghard, A.; Carlsson, L. Canonical Wnt/ $\beta$-catenin signalling is essential for optic cup formation. PloS One 2013, 8, e81158. [CrossRef]

116. Birdsey, G.M.; Shah, A.V.; Dufton, N.; Reynolds, L.E.; Osuna Almagro, L.; Yang, Y.; Aspalter, I.M.; Khan, S.T.; Mason, J.C.; Dejana, E.; et al. The endothelial transcription factor ERG promotes vascular stability and growth through Wnt/ß-catenin signaling. Dev. Cell 2015, 32, 82-96. [CrossRef]

117. Ye, X.; Wang, Y.; Cahill, H.; Yu, M.; Badea, T.C.; Smallwood, P.M.; Peachey, N.S.; Nathans, J. Norrin, frizzled-4, and Lrp5 signaling in endothelial cells controls a genetic program for retinal vascularization. Cell 2009, 139, 285-298. [CrossRef]

118. Zhou, Y.; Wang, Y.; Tischfield, M.; Williams, J.; Smallwood, P.M.; Rattner, A.; Taketo, M.M.; Nathans, J. Canonical WNT signaling components in vascular development and barrier formation. J. Clin. Invest. 2014, 124, 3825-3846. [CrossRef]

119. Huang, W.; Li, Q.; Amiry-Moghaddam, M.; Hokama, M.; Sardi, S.H.; Nagao, M.; Warman, M.L.; Olsen, B.R. Critical Endothelial Regulation by LRP5 during Retinal Vascular Development. PLoS ONE 2016, 11, e0152833. [CrossRef]

120. Shtutman, M.; Zhurinsky, J.; Simcha, I.; Albanese, C.; D’Amico, M.; Pestell, R.; Ben-Ze'ev, A. The cyclin D1 gene is a target of the beta-catenin/LEF-1 pathway. Proc. Natl. Acad. Sci. USA 1999, 96, 5522-5527. [CrossRef]

121. Angers, S.; Moon, R.T. Proximal events in Wnt signal transduction. Nat. Rev. Mol. Cell Biol. 2009. [CrossRef]

122. Cruciat, C.-M.; Niehrs, C. Secreted and transmembrane wnt inhibitors and activators. Cold Spring Harb. Perspect. Biol. 2013, 5, a015081. [CrossRef]

123. Aberle, H.; Bauer, A.; Stappert, J.; Kispert, A.; Kemler, R. $\beta$-catenin is a target for the ubiquitin-proteasome pathway. EMBO J. 1997, 16, 3797-3804. [CrossRef] [PubMed] 
124. Wu, D.; Pan, W. GSK3: A multifaceted kinase in Wnt signaling. Trends Biochem. Sci. 2010, 35, 161-168. [CrossRef] [PubMed]

125. Hur, E.-M.; Zhou, F.-Q. GSK3 signalling in neural development. Nat. Rev. Neurosci. 2010, 11, $539-551$. [CrossRef] [PubMed]

126. Ambacher, K.K.; Pitzul, K.B.; Karajgikar, M.; Hamilton, A.; Ferguson, S.S.; Cregan, S.P. The JNK- and AKT/GSK3 $\beta$ - Signaling Pathways Converge to Regulate Puma Induction and Neuronal Apoptosis Induced by Trophic Factor Deprivation. PLoS ONE 2012, 7, e46885. [CrossRef]

127. Tuo, J.; Wang, Y.; Cheng, R.; Li, Y.; Chen, M.; Qiu, F.; Qian, H.; Shen, D.; Penalva, R.; Xu, H.; et al. Wnt signaling in age-related macular degeneration: Human macular tissue and mouse model. J. Transl. Med. 2015, 13, 330. [CrossRef]

128. Park, K.; Lee, K.; Zhang, B.; Zhou, T.; He, X.; Gao, G.; Murray, A.R.; Ma, J.-X. Identification of a novel inhibitor of the canonical Wnt pathway. Mol. Cell. Biol. 2011, 31, 3038-3051. [CrossRef]

129. Dai, Z.; Lu, L.; Yang, Z.; Mao, Y.; Lu, J.; Li, C.; Qi, W.; Chen, Y.; Yao, Y.; Li, L.; et al. Kallikrein-binding protein inhibits LPS-induced TNF- $\alpha$ by upregulating SOCS3 expression. J. Cell. Biochem. 2013, 114, 1020-1028. [CrossRef]

130. Zhang, J.; Yang, Z.; Li, P.; Bledsoe, G.; Chao, L.; Chao, J. Kallistatin antagonizes Wnt/ $\beta$-catenin signaling and cancer cell motility via binding to low-density lipoprotein receptor-related protein 6. Mol. Cell. Biochem. 2013, 379, 295-301. [CrossRef]

131. Lu, S.-L.; Tsai, C.-Y.; Luo, Y.-H.; Kuo, C.-F.; Lin, W.-C.; Chang, Y.-T.; Wu, J.-J.; Chuang, W.-J.; Liu, C.-C.; Chao, L.; et al. Kallistatin modulates immune cells and confers anti-inflammatory response to protect mice from group A streptococcal infection. Antimicrob. Agents Chemother. 2013, 57, 5366-5372. [CrossRef] [PubMed]

132. McBride, J.D.; Jenkins, A.J.; Liu, X.; Zhang, B.; Lee, K.; Berry, W.L.; Janknecht, R.; Griffin, C.T.; Aston, C.E.; Lyons, T.J.; et al. Elevated circulation levels of an antiangiogenic SERPIN in patients with diabetic microvascular complications impair wound healing through suppression of Wnt signaling. J. Invest. Dermatol. 2014, 134, 1725-1734. [CrossRef] [PubMed]

133. Bach, R.R. Initiation of coagulation by tissue factor. CRC Crit. Rev. Biochem. 1988, 23, 339-368. [CrossRef] [PubMed]

134. Tuo, J.; Bojanowski, C.M.; Zhou, M.; Shen, D.; Ross, R.J.; Rosenberg, K.I.; Cameron, D.J.; Yin, C.; Kowalak, J.A.; Zhuang, Z.; et al. Murine ccl2/cx3cr1 deficiency results in retinal lesions mimicking human age-related macular degeneration. Invest. Ophthalmol. Vis. Sci. 2007, 48, 3827-3836. [CrossRef] [PubMed]

135. Chan, C.-C.; Ross, R.J.; Shen, D.; Ding, X.; Majumdar, Z.; Bojanowski, C.M.; Zhou, M.; Salem, N.; Bonner, R.; Tuo, J. Ccl2/Cx3cr1-deficient mice: An animal model for age-related macular degeneration. Ophthalmic Res. 2008, 40, 124-128. [CrossRef]

136. Chu, X.K.; Wang, Y.; Ardeljan, D.; Tuo, J.; Chan, C.-C. Controversial view of a genetically altered mouse model of focal retinal degeneration. Bioengineered 2013, 4, 130-135. [CrossRef]

137. Tuo, J.; Ross, R.J.; Herzlich, A.A.; Shen, D.; Ding, X.; Zhou, M.; Coon, S.L.; Hussein, N.; Salem, N.; Chan, C.-C. A high omega-3 fatty acid diet reduces retinal lesions in a murine model of macular degeneration. Am. J. Pathol. 2009, 175, 799-807. [CrossRef]

138. Tuo, J.; Pang, J.-J.; Cao, X.; Shen, D.; Zhang, J.; Scaria, A.; Wadsworth, S.C.; Pechan, P.; Boye, S.L.; Hauswirth, W.W.; et al. AAV5-mediated sFLT01 gene therapy arrests retinal lesions in Ccl2(-/-)/Cx3cr1(-/-) mice. Neurobiol. Aging 2012, 33, 433.e1-433.e10. [CrossRef]

139. Zhang, J.; Tuo, J.; Cao, X.; Shen, D.; Li, W.; Chan, C.-C. Early degeneration of photoreceptor synapse in $\mathrm{Ccl} 2 / \mathrm{Cx} 3 \mathrm{cr} 1-$ deficient mice on Crb1(rd8) background. Synap. N. Y. N 2013, 67, 515-531. [CrossRef]

140. Clemons, T.E.; Milton, R.C.; Klein, R.; Seddon, J.M.; Ferris, F.L. Age-Related Eye Disease Study Research Group Risk factors for the incidence of Advanced Age-Related Macular Degeneration in the Age-Related Eye Disease Study (AREDS) AREDS report no. 19. Ophthalmology 2005, 112, 533-539.

141. Wang, Y.; Sang, A.; Zhu, M.; Zhang, G.; Guan, H.; Ji, M.; Chen, H. Tissue factor induces VEGF expression via activation of the Wnt/ $\beta$-catenin signaling pathway in ARPE-19 cells. Mol. Vis. 2016, 22, 886-897. [PubMed]

142. Chen, Y.; Hu, Y.; Lu, K.; Flannery, J.G.; Ma, J.-X. Very low density lipoprotein receptor, a negative regulator of the wnt signaling pathway and choroidal neovascularization. J. Biol. Chem. 2007, 282, 34420-34428. [CrossRef] [PubMed] 
143. Voorzanger-Rousselot, N.; Goehrig, D.; Facon, T.; Clézardin, P.; Garnero, P. Platelet is a major contributor to circulating levels of Dickkopf-1: Clinical implications in patients with multiple myeloma. Br. J. Haematol. 2009, 145, 264-266. [CrossRef] [PubMed]

144. Oh, H.; Takagi, H.; Takagi, C.; Suzuma, K.; Otani, A.; Ishida, K.; Matsumura, M.; Ogura, Y.; Honda, Y. The potential angiogenic role of macrophages in the formation of choroidal neovascular membranes. Invest. Ophthalmol. Vis. Sci. 1999, 40, 1891-1898. [PubMed]

145. Cousins, S.W.; Espinosa-Heidmann, D.G.; Csaky, K.G. Monocyte activation in patients with age-related macular degeneration: A biomarker of risk for choroidal neovascularization? Arch. Ophthalmol. Chic. Ill 1960 2004, 122, 1013-1018. [CrossRef]

146. Duguid, I.G.; Boyd, A.W.; Mandel, T.E. Adhesion molecules are expressed in the human retina and choroid. Curr. Eye Res. 1992, 11 Suppl, 153-159. [CrossRef]

147. Elner, S.G.; Elner, V.M.; Pavilack, M.A.; Todd, R.F.; Mayo-Bond, L.; Franklin, W.A.; Strieter, R.M.; Kunkel, S.L.; Huber, A.R. Modulation and function of intercellular adhesion molecule-1 (CD54) on human retinal pigment epithelial cells. Lab. Investig. J. Tech. Methods Pathol. 1992, 66, 200-211.

148. Oguma, K.; Oshima, H.; Oshima, M. Inflammation, tumor necrosis factor and Wnt promotion in gastric cancer development. Future Oncol. Lond. Engl. 2010, 6, 515-526. [CrossRef]

149. Schön, S.; Flierman, I.; Ofner, A.; Stahringer, A.; Holdt, L.M.; Kolligs, F.T.; Herbst, A. $\beta$-catenin regulates NF- $\mathrm{B}$ activity via TNFRSF19 in colorectal cancer cells. Int. J. Cancer 2014, 135, 1800-1811. [CrossRef]

150. Anderson, D.H.; Mullins, R.F.; Hageman, G.S.; Johnson, L.V. A role for local inflammation in the formation of drusen in the aging eye. Am. J. Ophthalmol. 2002, 134, 411-431. [CrossRef]

151. Donoso, L.A.; Kim, D.; Frost, A.; Callahan, A.; Hageman, G. The role of inflammation in the pathogenesis of age-related macular degeneration. Surv. Ophthalmol. 2006, 51, 137-152. [CrossRef] [PubMed]

152. Chen, T.L. Inhibition of growth and differentiation of osteoprogenitors in mouse bone marrow stromal cell cultures by increased donor age and glucocorticoid treatment. Bone 2004, 35, 83-95. [CrossRef] [PubMed]

153. Soták, M.; Sumová, A.; Pácha, J. Cross-talk between the circadian clock and the cell cycle in cancer. Ann. Med. 2014, 46, 221-232. [CrossRef] [PubMed]

154. Guo, B.; Chatterjee, S.; Li, L.; Kim, J.M.; Lee, J.; Yechoor, V.K.; Minze, L.J.; Hsueh, W.; Ma, K. The clock gene, brain and muscle Arnt-like 1, regulates adipogenesis via Wnt signaling pathway. FASEB J. Off. Publ. Fed. Am. Soc. Exp. Biol. 2012, 26, 3453-3463.

155. Yasuniwa, Y.; Izumi, H.; Wang, K.-Y.; Shimajiri, S.; Sasaguri, Y.; Kawai, K.; Kasai, H.; Shimada, T.; Miyake, K.; Kashiwagi, E.; et al. Circadian disruption accelerates tumor growth and angio/stromagenesis through a Wnt signaling pathway. PLoS ONE 2010, 5, e15330. [CrossRef]

156. Janich, P.; Pascual, G.; Merlos-Suárez, A.; Batlle, E.; Ripperger, J.; Albrecht, U.; Cheng, H.-Y.M.; Obrietan, K.; Di Croce, L.; Benitah, S.A. The circadian molecular clock creates epidermal stem cell heterogeneity. Nature 2011, 480, 209-214. [CrossRef]

157. Lin, F.; Chen, Y.; Li, X.; Zhao, Q.; Tan, Z. Over-expression of circadian clock gene Bmal1 affects proliferation and the canonical Wnt pathway in NIH-3T3 cells. Cell Biochem. Funct. 2013, 31, 166-172. [CrossRef]

158. Sahar, S.; Sassone-Corsi, P. Metabolism and cancer: The circadian clock connection. Nat. Rev. Cancer 2009, 9, 886-896. [CrossRef]

159. Yang, X.; Wood, P.A.; Ansell, C.M.; Ohmori, M.; Oh, E.-Y.; Xiong, Y.; Berger, F.G.; Peña, M.M.O.; Hrushesky, W.J.M. Beta-catenin induces beta-TrCP-mediated PER2 degradation altering circadian clock gene expression in intestinal mucosa of ApcMin/+ mice. J. Biochem. (Tokyo) 2009, 145, 289-297. [CrossRef]

160. Duffield, G.E.; Best, J.D.; Meurers, B.H.; Bittner, A.; Loros, J.J.; Dunlap, J.C. Circadian programs of transcriptional activation, signaling, and protein turnover revealed by microarray analysis of mammalian cells. Curr. Biol. CB 2002, 12, 551-557. [CrossRef]

161. Sancar, A.; Lindsey-Boltz, L.A.; Unsal-Kaçmaz, K.; Linn, S. Molecular mechanisms of mammalian DNA repair and the DNA damage checkpoints. Annu. Rev. Biochem. 2004, 73, 39-85. [CrossRef] [PubMed]

162. Vander Heiden, M.G.; Cantley, L.C.; Thompson, C.B. Understanding the Warburg effect: The metabolic requirements of cell proliferation. Science 2009, 324, 1029-1033. [CrossRef] [PubMed]

163. Lum, J.J.; Bui, T.; Gruber, M.; Gordan, J.D.; DeBerardinis, R.J.; Covello, K.L.; Simon, M.C.; Thompson, C.B. The transcription factor HIF-1alpha plays a critical role in the growth factor-dependent regulation of both aerobic and anaerobic glycolysis. Genes Dev. 2007, 21, 1037-1049. [CrossRef] [PubMed] 
164. Suda, T.; Takubo, K.; Semenza, G.L. Metabolic regulation of hematopoietic stem cells in the hypoxic niche. Cell Stem Cell 2011, 9, 298-310. [CrossRef]

165. Brugarolas, J.B.; Vazquez, F.; Reddy, A.; Sellers, W.R.; Kaelin, W.G. TSC2 regulates VEGF through mTOR-dependent and -independent pathways. Cancer Cell 2003, 4, 147-158. [CrossRef]

166. Düvel, K.; Yecies, J.L.; Menon, S.; Raman, P.; Lipovsky, A.I.; Souza, A.L.; Triantafellow, E.; Ma, Q.; Gorski, R.; Cleaver, S.; et al. Activation of a Metabolic Gene Regulatory Network Downstream of mTOR Complex 1. Mol. Cell 2010, 39, 171-183. [CrossRef]

167. Jung, J.E.; Lee, H.G.; Cho, I.H.; Chung, D.H.; Yoon, S.-H.; Yang, Y.M.; Lee, J.W.; Choi, S.; Park, J.-W.; Ye, S.-K.; et al. STAT3 is a potential modulator of HIF-1-mediated VEGF expression in human renal carcinoma cells. FASEB J. Off. Publ. Fed. Am. Soc. Exp. Biol. 2005, 19, 1296-1298. [CrossRef]

168. Land, S.C.; Tee, A.R. Hypoxia-inducible factor 1alpha is regulated by the mammalian target of rapamycin (mTOR) via an mTOR signaling motif. J. Biol. Chem. 2007, 282, 20534-20543. [CrossRef]

169. Toschi, A.; Lee, E.; Gadir, N.; Ohh, M.; Foster, D.A. Differential dependence of hypoxia-inducible factors 1 alpha and 2 alpha on mTORC1 and mTORC2. J. Biol. Chem. 2008, 283, 34495-34499. [CrossRef]

170. Xu, Q.; Briggs, J.; Park, S.; Niu, G.; Kortylewski, M.; Zhang, S.; Gritsko, T.; Turkson, J.; Kay, H.; Semenza, G.L.; et al. Targeting Stat3 blocks both HIF-1 and VEGF expression induced by multiple oncogenic growth signaling pathways. Oncogene 2005, 24, 5552-5560. [CrossRef]

171. Pate, K.T.; Stringari, C.; Sprowl-Tanio, S.; Wang, K.; TeSlaa, T.; Hoverter, N.P.; McQuade, M.M.; Garner, C.; Digman, M.A.; Teitell, M.A.; et al. Wnt signaling directs a metabolic program of glycolysis and angiogenesis in colon cancer. EMBO J. 2014, 33, 1454-1473. [CrossRef] [PubMed]

172. Esen, E.; Chen, J.; Karner, C.M.; Okunade, A.L.; Patterson, B.W.; Long, F. WNT-LRP5 signaling induces Warburg effect through mTORC2 activation during osteoblast differentiation. Cell Metab. 2013, 17, 745-755. [CrossRef] [PubMed]

173. Sami, A.; Karsy, M. Targeting the PI3K/AKT/mTOR signaling pathway in glioblastoma: Novel therapeutic agents and advances in understanding. Tumour Biol. J. Int. Soc. Oncodevelopmental Biol. Med. 2013, 34, 1991-2002. [CrossRef] [PubMed]

174. Kim, J.; Gao, P.; Liu, Y.-C.; Semenza, G.L.; Dang, C.V. Hypoxia-inducible factor 1 and dysregulated c-Myc cooperatively induce vascular endothelial growth factor and metabolic switches hexokinase 2 and pyruvate dehydrogenase kinase 1. Mol. Cell. Biol. 2007, 27, 7381-7393. [CrossRef] [PubMed]

175. Semenza, G.L. HIF-1: Upstream and downstream of cancer metabolism. Curr. Opin. Genet. Dev. 2010, 20, 51-56. [CrossRef] [PubMed]

176. Shibuya, K.; Okada, M.; Suzuki, S.; Seino, M.; Seino, S.; Takeda, H.; Kitanaka, C. Targeting the facilitative glucose transporter GLUT1 inhibits the self-renewal and tumor-initiating capacity of cancer stem cells. Oncotarget 2015, 6, 651-661. [CrossRef] [PubMed]

177. Sun, Q.; Chen, X.; Ma, J.; Peng, H.; Wang, F.; Zha, X.; Wang, Y.; Jing, Y.; Yang, H.; Chen, R.; et al. Mammalian target of rapamycin up-regulation of pyruvate kinase isoenzyme type M2 is critical for aerobic glycolysis and tumor growth. Proc. Natl. Acad. Sci. USA 2011, 108, 4129-4134. [CrossRef]

178. Yeung, S.J.; Pan, J.; Lee, M.-H. Roles of p53, MYC and HIF-1 in regulating glycolysis - the seventh hallmark of cancer. Cell. Mol. Life Sci. CMLS 2008, 65, 3981-3999. [CrossRef]

(C) 2020 by the authors. Licensee MDPI, Basel, Switzerland. This article is an open access article distributed under the terms and conditions of the Creative Commons Attribution (CC BY) license (http://creativecommons.org/licenses/by/4.0/). 